\title{
Saluran Komunikasi Politik dalam Pembangunan Demokrasi pada Pemilu Legislatif DPR-RI di Kota Bogor 2019
}

\section{Political Communication in The Development of Democracy on Legislative Election of DPR-RI in Bogor City}

\author{
Redy Hendra Gunawan
}

Program Magister Ilmu Komunikasi, Universitas Paramadina, Jakarta 12790, Indonesia

E-mail korespondensi: redy@indekstat.com

Diterima: 23 Juni 2020 Direvisi: 14 Juli 2020 Disetujui: 17 Juli $2020 \quad$ Publikasi Online: 22 Juli 2020

\section{ABSTRACT}

In developing democracy, political communication is needed through various existing communication channels, especially in elections where the public needs a lot of political information needed as material in determining political decisions. This study aims to determine the effect of mass political communication channels, interpersonal communication channels and organizational communication channels on the decision to vote for parties in the DPR RI legislative elections in Bogor City in 2019. The research uses quantitative methods with a survey design with a sample of 240 voters in Bogor City. Determination of the sample using multistage random sampling techniques and data obtained using multinominal logistic regression analysis. The results showed that open campaigns, social media, blusukan, volunteers and religious leaders influenced the decision significantly to vote the party. Meanwhile, television media, billboards / posters, newspapers and face-to-face dialogues proved to have no effect in the decision to vote.

Keywords: democracy building, development communication, legislative elections, political communication channels, voting decisions

\section{ABSTRAK}

Dalam pembangunan demokrasi, diperlukan komunikasi politik melalui berbagai saluran komunikasi yang ada, terutama pada pemilihan umum dimana masyarakat membutuhkan banyak informasi politik yang dibutuhkan sebagai bahan dalam menentukan keputusan politiknya. Penelitian ini bertujuan untuk mengetahui pengaruh saluran komunikasi politik massa, saluran komunikasi interpersonal dan saluran komunikasi organisasi terhadap keputusan memilih partai pada pemilu legislatif DPR RI di Kota Bogor tahun 2019. Penelitian menggunakan metode kuantitatif dengan rancangan survei dengan sampel sebanyak 240 orang pemilih di Kota Bogor. Penentuan sampel menggunakan teknik multistage random sampling dan data dioleh dengan menggunakan analisis regresi logistik multinominal. Hasil penelitian menunjukkan bahwa kampanye terbuka, media sosial, blusukan, relawan dan tokoh agama mempengaruhi secara signifikan terhadap keputusan memilih partai. Sedangkan, media televisi, baliho/poster, koran dan dialog tatap muka terbukti tidak berpengaruh signifikan dalam keputusan memilih.

Kata kunci: keputusan memilih, komunikasi pembangunan, pembangunan demokrasi, pemilu legislatif, saluran komunikasi politik 


\section{PENDAHULUAN}

Pemilu merupakan sebuah pesta demokrasi yang dilakukan oleh suatu negara. Partisipasi masyarakat secara keseluruhan dalam pelaksanaan pemilu ini dipandang sebagai suatu wujud dari partisipasi politik dan partisipasi pemerintahan. Sistem politik di Indonesia berdasarkan pada nilai, prinsip, prosedur, dan kelembagaan yang demokratis (Sanit, 2015). Maknanya adalah demokrasi berkembang menjadi komponen penting dalam berbangsa dan bernegara. Salah satu bentuk perwujudan dari sistem demokrasi adalah keterlibatan rakyat secara langsung untuk memilih perwakilannya di legislatif dari pusat hingga ke daerah, presiden dan wakil presidennya hingga pemilihan langsung terhadap kepala daerahnya masing-masing.

Pemilihan umum tahun 2019 yang baru saja berlangsung memberikan pelajaran politik baik bagi masyarakat Indonesia yang berpartisipasi sebagai pemilih maupun bagi partai politik dan kandidat yang ikut serta berkompetisi pada pesta demokrasi tersebut. Selain itu, fenomena yang muncul dari tiap pelaksanaan pemilu tersebut tentunya berbeda-beda. Seperti halnya pelaksanaan pemilu 2019 yang berlangsung secara serentak, yakni pemilihan presiden-wakil presiden dilaksanakan bersamaan dengan pemilihan legislatif, yang mana hal tersebut belum pernah terjadi pada pemilu-pemilu sebelumnya. Keterlibatan langsung pemilih mengakibatkan adanya beragam saluran komunikasi politik yang digunakan oleh partai peserta pemilu. Setiap peserta pemilu melakukan komunikasi politik untuk dapat menyampaikan pesan-pesan politiknya kepada masyarakat.

Komunikasi politik merupakan upaya elit untuk mempengaruhi masyarakat agar gagasan politik yang memiliki substansi ideologi, orientasi politik dan pemikiran mempengaruhi masyarakat untuk mengambil keputusan politik yang demokratis, transparan dan akuntabilitas (Aly, 2010). Komunikasi politik juga melibatkan banyak elemen pada lingkungan kelembagaan, organisasi dan budaya yang abadi dan berkelanjutan (Hallin \& Mancini, 2004). Oleh karena itu, komunikasi politik menjadi suatu sistem yang menggabungkan berbagai ranah di masyarakat. Sistem komunikasi politik ini akan mempengaruhi sikap subjektif pada setiap warga negara untuk menciptakan pembangunan yang stabil dan berkelanjutan (Esser \& Pfetsch, 2004). Pesan-pesan politik yang memuat perubahan-perubahan sosial demi pembangunan negara perlu disampaikan secara efektif menggunakan saluran komunikasi yang ada. Saluran komunikasi politik sebagai salah satu komponen dalam komunikasi politik memiliki peran besar dalam mensukseskan program-program yang terdapat pada komunikasi pembangunan (Muhammad, 2016). Oleh karena itu, pengetahuan mengenai peran berbagai saluran komunikasi politik tersebut penting diketahui agar para aktor politik mampu menggunakan saluran komunikasi yang efektif untuk memberikan pengetahuan politik yang baik kepada masyarakat sehingga pembangunan demokrasi suatu negara dapat tercipta dengan baik.

Terdapat banyak penelitian yang menyelidiki peran saluran komunikasi politik dalam komunikasi pembangunan demokrasi. Penelitian yang dilakukan oleh (Aguirre \& Hyman, 2015) menekankan pentingnya kampanye pemilu dan membahas pentingnya iklan di televisi dalam rangka mempengaruhi pemilih. Quintelier \& Hooghe (2011) juga meneliti pengaruh dari televisi terhadap partisipasi politik dan menemukan bahwa terdapat dampak positif dari media televisi terhadap partisipasi politik pada pemilih muda. Namun, kedua penelitian tersebut hanya menyelidiki pengaruh pada satu media saja yaitu media televisi sebagai salah satu saluran komunikasi massa. Pada media luar ruang, terdapat Deželan \& Maksuti (2012) yang menyelidiki penggunaan poster pada pemilihan dan menyarankan untuk menekankan bahwa poster dapat mempengaruhi pemilih dengan menekankan pada warna, ukuran, pesan, bahasa, hal-hal font, dan menggunakan foto dan gambar. Penelitian yang dilakukan oleh Ron (2009) lebih komprehensif dan mengemukakan bahwa para kandidat dapat beriklan di televisi, radio, papan iklan, surat langsung, dan melalui telepon untuk menjangkau para pemilih. Namun, keseluruhan studi tersebut hanya melihat pengaruh dari saluran komunikasi massa dan tidak menyelidiki kedua saluran komunikasi lainnya. Padahal, menurut (Kaid, 2004) saluran komunikasi politik memiliki tiga saluran yaitu saluran komunikasi massa, interpersonal dan organisasi. Kedua saluran komunikasi lainnya masih minim literatur walaupun dari literatur yang ada menyatakan bahwa saluran komunikasi interpersonal memiliki dampak pada perolehan suara kandidat pada pemilihan (Gama et al., 2019a; Siagian, 2012). Begitupun untuk saluran komunikasi organisasi dinilai berpengaruh terhadap partisipasi pemilih (Hermanto et al., 2020).

Penelitian-penelitian tersebut menekankan pentingnya saluran komunikasi politik yang dinilai berpengaruh terhadap keputusan memilih. Namun, besarnya pengaruh antar saluran komunikasi politik 
tidak terlihat sehingga peserta pemilihan umum baik partai politik maupun kandidat belum mendapatkan pengetahuan yang menyeluruh dan taktis untuk digunakan sebagai dasar pemilihan saluran komunikasi politik. Padahal, pengetahuan mengenai besaran pengaruh setiap saluran komunikasi politik terhadap keputusan memilih sangat berguna untuk strategi kampanye, terlebih pemilihan umum di Indonesia yang melibatkan seluruh saluran komunikasi baik massa, interpersonal dan organisasi. Oleh karena itulah, penulis tertarik untuk membuat penelitian yang menyelidiki peran seluruh komponen saluran komunikasi politik.

Kota Bogor merupakan wilayah yang dikelompokkan oleh KPU sebagai Daerah Pemilihan (Dapil) Jawa Barat 3. Wilayah tersebut memiliki tingkat partisipasi pemilih yang tinggi (KPU, 2019). Pemilu legislatif di Kota Bogor dapat menjadi pembelajaran tentang saluran komunikasi politik yang berperan dalam mempengaruhi perilaku pemilih. Hal tersebut dikarenakan saluran komunikasi politik yang tersedia cukup banyak, diantaranya terdapat saluran komunikasi politik yang meliputi kampanye terbuka, iklan dan pemberitaan di berbagai media massa, dialog tatap muka dan blusukan yang dilakukan oleh partai peserta pemilu, relawan politik dan juga tokoh masyarakat yang dijadikan komunikator politik oleh partai peserta pemilu. Partai peserta pemilu menggunakan seluruh saluran komunikasi politik tersebut dalam berkampanye tanpa memiliki pengetahuan mengenai saluran komunikasi politik mana yang paling signifikan mempengaruhi perilaku pemilih. Oleh karena itu, peneliti ingin mengetahui peran saluran komunikasi politik terhadap keputusan memilih pada pemilu legislatif DPR RI Kota Bogor 2019. Tujuan dari penelitian secara spesifik untuk mengetahui pengaruh saluran komunikasi politik yang memiliki signifikansi paling besar, yang terdiri dari saluran komunikasi massa, saluran komunikasi interpersonal dan organisasi terhadap keputusan memilih partai pada pemilu legislatif DPR RI Kota Bogor tahun 2019.

\section{Komunikasi Politik dan Keputusan Memilih}

Menurut Subakti (2007) komunikasi politik merupakan sebuah proses penyampaian informasi mengenai politik dari pemerintah kepada masyarakat ataupun dari masyarakat kepada pemerintah. Komunikasi politik disebut juga sebagai bidang disiplin ilmu yang mempelajari perilaku dan kegiatan komunikasi yang mengandung unsur politik serta memiliki pengaruh politis (Cangara H, 2009). Adapun tujuan komunikasi politik antara lain membangun citra politik, membentuk dan membina pendapat umum serta mendorong partisipasi politik (Anwar, 2003).

Tujuan komunikasi politik yang pertama yaitu membangun citra politik yang baik bagi khalayak. Informasi yang diterima oleh masyarakat baik langsung ataupun melalui media politik akan membentuk citra politik di msyarakat. Selain itu, komunikasi politik juga bertujuan untuk membentuk pendapat umum melalui peranan media politik terutama media massa. Media massa memiliki fungsi mendidik, menghubungkan dan menghibur sekaligus membentuk citra politik dan pendapat umum yang menjadi dimensi penting dalam kehidupan politik. Selanjutnya, komunikasi polittik akan mampu mendorong partisipasi politik. Partisipasi politik dimaksudkan agar individu-individu berperan serta dalam kegiatan politik.

Komunikasi politik memiliki saluran komunikasi untuk menyampaikan pesan-pesan politik dari komunikator politik kepada khalayak yang hendak dituju. Saluran adalah ciptaan orang-orang yang menggunakan lambang-lambang untuk saling tukar menukar pesan, yang harus lebih diutamakan adalah manusianya sendiri yang paling asasi bagi komunikasi politik. Dalam konteks ini, terdapat tiga saluran komunikasi politik yang penting untuk dipergunakan dalam setiap kampanye politik, yaitu saluran komunikasi massa, saluran komunikasi interpersonal dan saluran komunikasi organisasi (Kaid, 2004).

Saluran komunikasi massa terdiri dari dua bentuk: pertama, komunikasi tatap muka, seperti bila seorang kandidat berbicara di depan umum. Bentuk komunikasi massa yang kedua yaitu dengan menggunakan perantara yang ditempatkan di antara komunikator dan khalayak seperti media, teknologi, sarana dan alat komunikasi lainnya. Beberapa saluran komunikasi massa yang digunakan pada pemilu legislatif di Kota Bogor pada tahun 2019 diantaranya adalah kampanye terbuka, media massa televisi, media sosial, media luar ruang (baliho/poster) dan koran.

Pada dasarnya, kampanye merupakan bentuk penyampaian pesan dari pengirim kepada khalayak. Pesan tersebut disampaikan dengan menggunakan berbagai bentuk mulai dari media, dialog hingga kampanye terbuka (Venus, 2004). Pengertian kampanye berdasarkan UU Nomor 1 Tahun 2015 
tentang Pemilihan Umum Anggota Dewan Perwakilan Rakyat, Dewan Perwakilan Daerah, Dan Dewan Perwakilan Rakyat Daerah pada pasal 1 ayat 26 adalah kegiatan peserta pemilu untuk meyakinkan para pemilih dengan menawarkan visi, misi, dan program peserta pemilu. Sementara itu, kampanye terbuka merupakan istilah lain dari Rapat Umum dalam UU Pemilu Tahun 2017. Pada kampanye terbuka, para peserta pemilu diperkenankan untuk melakukan pengumpulan massa dalam skala besar baik berupa konvoy massa ataupun pada titik kumpul tertentu untuk mensosialisasikan program kerja.

H1: Kampanye terbuka (X1) berpengaruh signifikan terhadap keputusan memilih partai (Y).

Menurut penelitian dari Gerber et al., (2011) mengemukakan bahwa para kandidat dapat beriklan di televisi, radio, papan iklan, surat langsung, dan melalui telepon untuk menjangkau para pemilih. Penelitian tersebut sejalan dengan apa yang disampaikan oleh Gordon \& Hartmann (2013) dalam karya terobosan mereka di AS. Mereka juga berpendapat bahwa iklan politik di berbagai media terutama televisi, memengaruhi hasil pemilu. Oleh karena itu, penelitian ini juga mengambil media massa berupa televisi, koran, dan baliho/poster sebagai variabel penelitian yang diduga memiliki pengaruh terhadap keputusan memilih. Begitupula dengan media sosial yang dianggap sebagai new media saat ini. Menurut Safiullah et al., (2017) media sosial memiliki dampak positif dan signifikan terhadap hasil pemilihan umum 2014 di India. Media sosial didefinisikan sebagai jaringan informasi baru dan teknologi informasi dengan menggunakan suatu bentuk komunikasi menggunakan konten interaktif serta hubungan interpersonal yang diciptakan dan dipelihara dengan baik. Media sosial memiliki layanan jaringan yang khas berupa fitur untuk berbagi konten dan meninggalkan komentar pada komunitas ataupun forum internet.

H2: Media massa televisi (X2) berpengaruh signifikan terhadap keputusan memilih partai (Y).

H3: Media sosial (X3) berpengaruh signifikan terhdap keputusan memilih partai (Y).

H4: Baliho dan poster (X4) berpengaruh signifikan terhadap keputusan memilih partai (Y)

H5: Koran (X5) berpengaruh signifikan terhadap keputusan memilih partai(Y).

Selain saluran komunikasi massa, terdapat juga saluran komunikasi interpersonal yang merupakan bentuk hubungan satu sama lain yang terdiri dari saling tukar kata lisan di antara dua orang atau lebih. Saluran ini bisa berbentuk tatap muka maupun berperantara. Saluran komunikasi interpersonal yang sering digunakan oleh peserta pemilu yaitu dialog tatap muka, blusukan dan relawan.

Sesuai dengan dengan Peraturan KPU (PKPU) No 33 Tahun 2018, salah satu bentuk kampanye adalah dengan dialog tatap muka. Dialog tatap muka merupakan bentuk kampanye yang dilakukan secara terbatas dan bersifat interaktif (KPU, 2018). Sementara itu, istilah blusukan dikenal dalam bahasa Jawa dialek Solo. Blusukan diartikan sebagai "Perjalanan ke tempat-tempat jauh". Dalam konteks kebijakan publik blusukan dilakukan karena mempunyai peranan sebagai wahana bagi pemimpin untuk menangkap aspirasi rakyat secara langsung. Dalam konteks komunikasi politik terutama pada saat kampanye, blusukan dilakukan untuk mendapatkan dukungan suara pada saat dilakukan pemungutan suara (Gama et al., 2019b). Menurut Siagian (2012) relawan politik merupakan salah satu komunikator politik yang berperan penting dalam mentransfer ide dan saran untuk penonton.

H6: Dialog tatap muka (X6) berpengaruh signifikan terhadap keputusan memilih partai (Y)

H7: Blusukan (X7) berpengaruh signifikan terhadap keputusan memilih partai (Y).

H8: Relawan (X8) berpengaruh signifikan terhadap keputusan memilih partai (Y).

Saluran komunikasi lainnya yang biasa digunakan dalam komunikasi politik adalah saluran komunikasi organisasi yang merupakan jaringan komunikasi dari organisasi yang menggabungkan sifat-sifat dari saluran komunikasi massa dan interpersonal. Tentu saja ada jenis-jenis organisasi yang sangat berbeda dalam politik, baik formal maupun informal. Kelompok informal adalah keluarga seseorang, kelompok sebaya, dan rekan kerja yang semuanya memainkan peran penting dalam mengembangkan opini politik. Sedangkan kelompok formal meliputi partai politik dan berbagai organisasi kepentingan khusus, seperti serikat buruh, asosiasi perusahaan, pembela konsumen, organisasi hak sipil, dan koalisi kebebasan wanita. Pada pemilu legislatif Kota Bogor, saluran komunikasi organisasi yang sering digunakan adalah tokoh agama.

H9: Tokoh agama (X11) berpengaruh signifikan terhadap keputusan memilih partai (Y). 
Para peserta pemilu menggunakan berbagai saluran komunikasi politik tersebut untuk menyampaikan pesan-pesan politiknya dan pada akhirnya mencoba untuk mempengaruhi keputusan memilih masyarakat. Memilih merupakan aktifitas yang menentukan keputusan baik secara langsung ataupun tidak langsung. Subakti (2007) menilai perilaku memilih ialah keikutsertaan warga negara dalam pemilihan umum merupakan serangkaian kegiatan membuat keputusan, yakni apakah memilih atau tidak memilih dalam pemilihan umum. Memilih dalam menentukan kandidat dapat melalui proses tertentu, sama halnya dengan seorang konsumen dalam memutuskan membeli sebuah produk. Sumarwan (2003) menyatakan bahwa keputusan pembelian adalah keputusan seseorang untuk memilih salah satu dari beberapa opsi alternatif. Keputusan pembelian adalah proses yang terintegrasi dan melibatkan pengetahuan gabungan untuk mengevaluasi dua atau lebih perilaku alternatif dan kemudian memilih layanan yang sesuai. Cwalina et al., (2015) berpendapat, sehubungan dengan penetapan pilihan, tidak jarang juga pemilih dapat mengubah pilihannya di saat-saat terakhir karena pengaruh sikap dari orang lain dan situasi tak terduga pada menit-menit terakhir atau yang sering disebut sebagai swing-voters. Model proses keputusan pemilihan tersebut dimulai dari mengenali kebutuhan, melakukan pencarian informasi, melakukan evaluasi alternatif hingga menghasilkan keputusan pilihan yang dipengaruhi oleh sikap orang lain dan sikap tak terduga lainnya.

\section{METODE}

\section{Partisipan}

Penelitian ini menggunakan metode kuantitatif dengan rancangan survei. Metode kuantitatif adalah metode yang dapat digunakan untuk menguji teori tertentu dengan cara meneliti hubungan antar variabel (Creswell, 2016). Tujuan penelitian dengan rancangan survei adalah untuk membuat kesimpulan atau dugaan sementara tentang beberapa kecenderungan, seperti: karakteristik, perilaku, dan sikap dari populasi. Secara mendasar keunggulan rancangan survei dalam metode kuantitatif adalah keekonomisan dan kecepatan dalam menyajikan data, dan data yang diperoleh dapat mengidentifikasi sifat-sifat suatu populasi hingga pada tingkat individu (Sugiyono, 2017).

Adapun populasi pada penelitian ini adalah seluruh anggota masyarakat di Kota Bogor yang terdaftar di DPT (memiliki hak pilih). Penentuan sampel pada penelitian ini menggunakan teknik multistage random sampling. Teknik sampling disusun atas beberapa metode penarikan contoh, diantaranya stratified random sampling, cluster random sampling dan simple random sampling. Besarnya sampel sebanyak 240 sampel dengan margin of error sebesar $\pm 6,45 \%$. Metode analisis data yang digunakan dalam penelitian ini adalah metode analisis regresi logistik multinominal. Analisis regresi logistik multinominal digunakan untuk mengetahui saluran komunikasi yang menjadi faktor berpengaruh terhadap keputusan memilih partai pada pemilu legislatif DPR RI Kota Bogor. Pemrosesan data menggunakan perangkat lunak Microsoft Office Excel dan perangkat lunak SPSS.

\section{Prosedur}

Analisis regresi logistik multinomial merupakan regresi logistik yang digunakan saat variabel respon bersifat polychotomous atau multinomial, berskala nominal dan ordinal dengan lebih dari dua kategori. Model regresi untuk variabel respon yang lebih dari dua kategori harus memperhatikan skala pengukuran (Hosmer \& Lemeshow, 2000). Pada penelitian ini menggunakan model regresi logistik dengan variabel respon berskala nominal dan kategorik. Fungsi probabilitas regresi logistik untuk masing- masing kategori dapat di lihat pada persamaan berikut.

$$
\begin{gathered}
\pi 1(\mathrm{x})=P\left(Y=1 \mid=\frac{\exp g 1(x)}{1+\exp g 1(x)+\exp g 2(x)} .\right. \\
\pi 2(\mathrm{x})=P(Y=2 \mid x)=\frac{\exp g 2(x)}{1+\exp g 1(x)+\exp g 2(x)} . \\
\pi 3(\mathrm{x})=P(Y=3 \mid x)=\frac{1}{1+\exp g 1(x)+\exp g 2(x)} .
\end{gathered}
$$


Cumulative Logit Models didapatkan dengan membandingkan peluang kumulatif yaitu peluang kurang dari atau sama dengan kategori respon ke-j pada $p$ variabel prediktor yang dinyatakan dalam vektor $x_{i}$ $P\left(Y \leq j \mid x_{i}\right)$, dengan peluang lebih besar dari kategori respon ke-j, $P\left(Y>j \mid x_{i}\right)$ ([6]. Rumus cumulative logit models dapat dilihat pada persamaan berikut.

$$
\text { Logit } P(Y \leq j \mid x i)=\log \left(\frac{p(Y \leq j \mid x i}{p(Y \leq j \mid x i}\right)
$$

Sehingga secara umum, bentuk dari fungsi logit dengan variabel respon yang terdiri dari lebih dari dua kategori adalah seperti pada persamaan berikut.

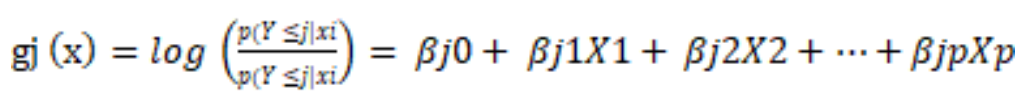

\section{Pengukuran}

Penelitian ini memiliki 9 variabel independen dan 1 variabel dependen. Penelitian menggunakan variabel independen antara lain kampanye terbuka, media massa televisi, media sosial, media luar ruang (baliho dan poster), media massa koran, dialog tatap muka, blusukan, relawan dan tokoh agama. Sementara itu variabel dependen terdiri dari keputusan memilih partai pada pemilu legislatif DPR RI. Model operasional dari variabel tersebut ditunjukkan pada Gambar 2 sebagai model konseptual penelitian.

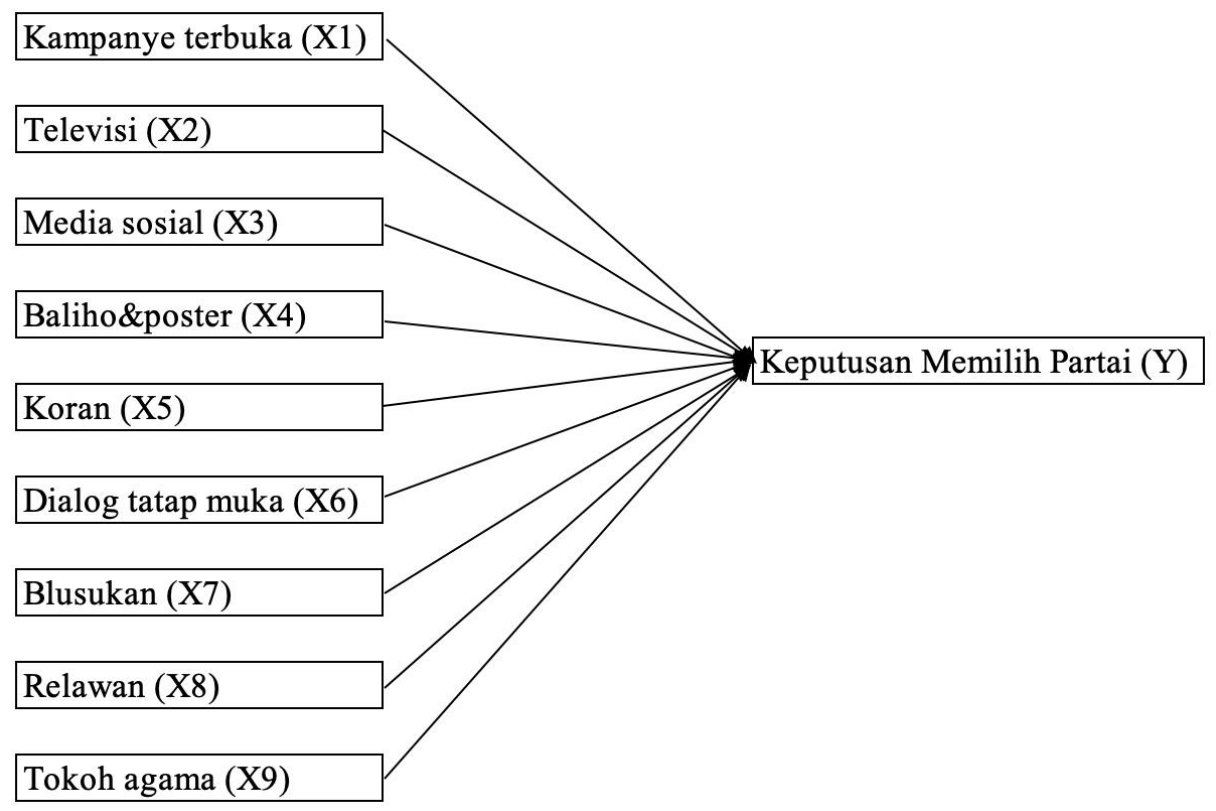

Gambar 2. Model konseptual penelitian

\section{HASIL DAN PEMBAHASAN}

Model penelitian diuji menggunakan analisis regresi logistik multinominal dengan hasil yang dapat dilihat pada Tabel 1 berikut ini.

Tabel 1. Hasil analisa regresi logistik multinominal

\begin{tabular}{lcccc}
\hline Effect & Model Fitting Criteria & \multicolumn{3}{c}{ Likelihood Ratio Tests } \\
& & Chi-Square & df. & Sig \\
\hline Intercept & $557.144 \mathrm{a}$ & .000 & 0 &.
\end{tabular}




\begin{tabular}{llrrr} 
Kampanye terbuka (X1) & $597.856 \mathrm{~b}$ & 40.722 & 26 & .033 \\
Televisi (X2) & $590.183 \mathrm{~b}$ & 33.039 & 26 & .161 \\
Medsos (X3) & $607.908 \mathrm{~b}$ & 50.765 & 26 & .003 \\
Baliho\&poster (X4) & $583.371 \mathrm{~b}$ & 26.227 & 26 & .451 \\
Koran (X5) & $586.052 \mathrm{~b}$ & 28.908 & 26 & .315 \\
Dialog tatap muka (X6) & $585.015 \mathrm{~b}$ & 27.872 & 26 & .365 \\
Blusukan (X7) & $6106.338 \mathrm{~b}$ & 5549.194 & 26 & .000 \\
Relawan (X8) & $606.545 \mathrm{~b}$ & 49.401 & 26 & .004 \\
Tokoh agama (X9) & $630.602 \mathrm{~b}$ & 73.458 & 39 & .001 \\
\hline
\end{tabular}

Berdasarkan hasil analisa regresi logistik multinominal diatas, terlihat bahwa variabel independen yang secara statistik signifikan mempengaruhi variabel dependen adalah variabel kampanye terbuka (X1), media sosial (X3), blusukan (X7), relawan (X8) dan tokoh agama (X9). Hal ini terlihat dari nilai probabilitas chi-square masing-masing variabel dependen yang lebih kecil dari nilai alfa 0,05 yaitu 0,033; 0,003; 0,000; 0,004 dan 0,001. Sedangkan variabel televisi (X2), baliho\&poster (X4), koran (X5) dan dialog tatap muka (X6) diketahui tidak berpengaruh signifikan karena nilai probabilitas chisquare yang lebih besar dari nilai alfa 0,05 yaitu sebesar 0,$161 ; 0,451 ; 0,315$ dan 0,365 . Hal tersebut menunjukkan bahwa pemilih Kota Bogor lebih dapat menerima pesan politik yang disampaikan partai peserta pemilu melalui kampanye terbuka, media sosial, blusukan, relawan dan tokoh agama. Sedangkan saluran komunikasi lainnya yaitu televisi, baliho \& poster, koran dan dialog tatap muka merupakan saluran komunikasi politik yang tidak efektif untuk digunakan.

Temuan penelitian menunjukkan bahwa masing-masing saluran komunikasi penelitian memiliki pengaruh yang berbeda-beda terhadap keputusan memilih. Saluran komunikasi politik interpersonal berupa blusukan merupakan saluran komunikasi paling efektif untuk digunakan dalam mempengaruhi keputusan memilih partai. Selanjutnya berturut turut adalah tokoh agama, media sosial, relawan dan kampanye terbuka. Hal ini sejalan dengan penelitian yang dilakukan oleh (Gama et al., 2019a). Hasil penelitiannya menunjukkan bahwa dengan blusukan, masyarakat merasa bangga dapat bertemu langsung dengan kandidat politik, blusukan telah mampu mempengaruhi perilaku pemilih potensial, dan blusukan sangat efektif selama kampanye.

Pada saluran komunikasi massa, media sosial adalah saluran yang dinilai paling efektif dalam mempengaruhi keputusan memilih. Hal ini dikarenakan semakin mudahnya masyarakat mengakses berita dari media sosial yang berada pada smartphone. Kemudahan ini mendorong masyarakat untuk lebih mudah menerima pesan-pesan politik dari media sosial. Hal ini sesuai dengan penelitian yang menyatakan bahwa media sosial adalah pendukung jaringan komunikasi politik dalam demokrasi negara (Susanto, 2017). Putra (2011) juga menyatakan bahwa pada pemilu 2004 dan 2009, penggunaan internet semakin meningkat pada partai politik, individu calon legislator, calon presiden dan calon wakil presiden. Begitupun yang terjadi di negara maju dan berkembang lainnya, internet dan ponsel sudah digunakan secara luas dalam kampanye pemilihan terbukti memiliki dampak pada perilaku politik (Riaz, 2014).

Selain media sosial, saluran komunikasi massa yang juga signifikan mempengaruhi keputusan memilih adalah kampanye terbuka. Penyampaian pesan dari para peserta pemilu dalam bentuk komunikasi massa dengan mengumpulkan massa dalam skala besar pada suatu tempat ini terbukti berpengaruh dalam mempengaruhi keputusan memilih. Namun, hasil penelitian menyatakan hal sebaliknya pada saluran komunikasi televisi dan surat kabar. Temuan penelitian menyatakan bahwa televisi dan surat kabar tidak berpengaruh pada keputusan memilih. Hal ini bertentangan dengan penelitian (O'cass, 2002) yang menyatakan bahwa media televisi dan koran dinilai sebagai sumber informasi oleh pemilih. Temuan penelitian terkait saluran komunikasi dalam bentuk baliho/poster juga memperlihatkan hasil yang bertentangan dangan penelitian sebelumnya yang dilakukan oleh Anshori (2018) menyatakan bahwa media luar ruang seperti baliho memiliki pengaruh terhadap keputusan memilih. Perbedaan hasil temuan bisa jadi dikarenakan adanya perkembangan teknologi, terutama internet dalam lima tahun terakhir sehingga televisi dan koran sudah tidak lagi menjadi saluran yang 
berpengaruh dibandingkan dengan sosial media dan kampanye terbuka. Hasil penelitian ini menyiratkan bahwa untuk saluran komunikasi massa, lebih baik para peserta pemilu mengalokasikan sumberdayanya pada media sosial dan kampanye terbuka yang telah terbukti berpengaruh pada keputusan memilih.

Pada saluran komunikasi politik interpersonal, blusukan dan relawan dinilai lebih berpengaruh terhadap keputusan memilih dibandingkan dialog tatap muka. Hasil penelitian menunjukkan blusukan yang dilakukan oleh tokoh partai dengan masuk ke daerah-daerah di Kota Bogor untuk berkomunikasi dengan warga setempat merupakan sarana yang efektif untuk menarik minat memilih masyarakat. Blusukan inilah yang menjadi salah satu cara efektif yang dilakukan oleh Joko Widodo untuk menarik minat masyarakat dan menjadikannya pemenang dalam pemilu. Menurut Zulkarnain \& Harris (2017) blusukan yang dilakukan oleh Joko Widodo merupakan bentuk dari kepemimpinan pelayan (servant leadership) yang diharapkan oleh masyarakat sehingga masyarakat dapat lebih dekat dalam berkomunikasi dengan kandidat. Saluran komunikasi politik interpersonal lainnya yang juga dinilai efektif yaitu relawan. Relawan yang mengkomunikasikan pesan-pesan politik partai secara interpersonal kepada masyarakat dinilai dapat mempengaruhi minat dan keputusan memilih masyarakat. Relawan politik juga dinilai dapat meningkatkan partisipasi publik dan secara positif berkontribusi terhadap pembangunan model demokrasi ekstra parlementer (Arianto, 2016). Sedangkan dialog tatap muka yang dilakukan oleh tokoh partai di suatu lokasi tertentu, dinilai tidak efektif untuk berkomunikasi dengan masyarakat. Temuan ini menegaskan bahwa para peserta pemilu lebih baik memilih berkomunikasi interpersonal dengan masyarakat melalui blusukan dan relawan yang terbukti berpengaruh secara signifikan terhadap keputusan memilih. Penggunaan kedua saluran komunikasi interpersonal ini dapat menyampaikan pesan-pesan politik dengan lebih efektif karena dapat diterima dengan baik oleh masyarakat dan mampu mempengaruhi perilaku politiknya. Oleh karena itu, sumberdaya yang semula dialokasikan untuk dialog tatap muka lebih baik dialihkan untuk membiayai kegiatan blusukan dan relawan yang terbukti lebih efektif.

Pada temuan penelitian mengenai saluran komunikasi organisasi melalui tokoh agama menunjukkan bahwa tokoh agama terbukti berpengaruh positif dan signifikan dalam mempengaruhi pemilih Kota Bogor. Tokoh agama sebagai orang yang berpengaruh di masyarakat memiliki kekuatan untuk mempengaruhi keputusan politik masyarakat Kota Bogor. Hal ini sejalan dengan Muslim et al. (2015) yang juga menyatakan bahwa tokoh agama memiliki peran yang besar terhadap dinamika politik di daerah. Oleh karena itu, penggunaan saluran komunikasi ini lebih baik untuk dipertahankan dan ditingkatkan oleh para tokoh politik yang ingin mempengaruhi masyarakat.

Dalam proses pemilihan, akan lebih baik jika partai peserta pemilu mengetahui dan menggunakan saluran komunikasi politik yang sudah terbukti memiliki pengaruh signifikan terhadap keputusan memilih. Penggunaan saluran komunikasi politik dalam bentuk kampanye terbuka, media sosial, blusukan, relawan dan tokoh agama dapat digunakan secara bersama pada kampanye pemilihan untuk mengkomunikasikan pesan-pesan politik sekaligus berupaya mempengaruhi keputusan pemilih. Dari variabel-variabel saluran komunikasi politik yang di bahas dalam penelitian ini, tidak semua variabel komunikasi politik berpengaruh secara signifikan terhadap keputusan pemilih. Partai Politik perserta pemilu sering kali tidak memahami variabel komunikasi politik mana yang berpengaruh secara signifikan, sehingga partai politik dan kandidat politik sering kali tidak memiliki gambaran yang akurat mengenai saluran komunikasi politik yang akan digunakan. Partai politik dan kandidat politik juga tidak menggunakan semua saluran sehingga kampanye yang dilakukan tidak secara komprehensif mempengaruhi keputusan pemilih. Dalam penelitian ini diketahui adanya lima saluran komunikasi politik tersebut perlu mendapatkan perhatian dan sumberdaya yang lebih besar dibandingkan saluran komunikasi politik lainnya. Sumber daya yang semula banyak digunakan untuk membiayai saluran komunikasi lainnya dapat ditinjau ulang untuk dialokasikan pada kelima saluran komunikasi politik tersebut. Hal ini akan dapat mengefektifkan sumberdaya dan kerja tim pemenangan.

Namun, temuan penelitian ini hanya terbatas pada pengaruh saluran komunikasi politik terhadap keputusan memilih. Temuan penelitian tidak membahas mengenai informasi yang disampaikan oleh masing-masing saluran komunikasi dan bagaimana penerimaan masyarakat terhadap informasi tersebut. Oleh karena itu, temuan peneltian tidak menjadi sebuah dasar untuk melegitimasi bahwa saluran komunikasi lainnya tidak dapat menyampaikan informasi kepada masyarakat. Saluran komunikasi lainnya tetap dapat digunakan oleh para pelaku politik untuk menyampaikan infomasi dan pesan-pesan politiknya. Namun, menurut penelitian ini hanya saluran komunikasi dalam bentuk 
kampanye terbuka, media sosial, blusukan, relawan dan tokoh agama yang berpengaruh signifikan terhadap keputusan memilih. Oleh karena itu, pada dasarnya seluruh saluran komunikasi politik tetap dapat digunakan secara bersama-sama namun dengan alokasi sumberdaya yang lebih diprioritaskan pada kelima saluran komunikasi yang terbukti berpengaruh signifikan pada keputusan memilih. Temuan ini dapat menjadi bahan masukan berharga bagi para konsultan politik ataupun partai peserta pemilu untuk dapat memenangkan proses pemilihan. Selain itu, temuan penelitian ini dapat menjadi bahan strategi pemasaran politik dalam berkampanye dengan menggunakan media kampanye terbuka, media sosial, blusukan, relawan dan tokoh agama.

Selain berkontribusi nyata bagi para pelaku politik, temuan penelitian ini juga berkontribusi untuk meningkatkan pemahaman mengenai komunikasi pembangunan dari sudut pandang komunikasi politik. Komunikasi politik yang terjalin antara masyarakat dengan para pemangku kepentingan dan jabatan akan sangat bermanfaat dalam komunikasi pembangunan. Saluran komunikasi politik yang efektif dapat memfasilitasi masyarakat dalam memperoleh informasi dan pengetahuan politik yang sangat berguna dalam membentuk keputusan memilihnya. Selain itu, saluran komunikasi menjadi media penghubung bagi masyarakat untuk dapat menyampaikan aspirasi dan kebutuhannya kepada para pelaku politik. Sesuai dengan temuan penelitian, bahwa blusukan sebagai saluran komunikasi interpersonal memiliki pengaruh yang lebih tinggi diantara lainnya. Oleh karena itu, para pelaku politik dan juga para pemangku jabatan pemerintahan dapat menggunakan blusukan dengan lebih intensif untuk dapat melakukan komunikasi dengan masyarakat dan pada akhirnya akan berkontribusi untuk membangun Indonesia. Selain blusukan, komunikasi pembangunan melalui komunikasi politik juga dapat menggunakan tokoh agama, relawan dan media sosial untuk menjalin komunikasi yang berkesinambungan bagi pembangunan di Indonesia.

\section{KESIMPULAN}

Dalam pembangunan demokrasi, khususnya pemilihan umum diperlukan komunikasi politik yang efektif dari para peserta pemilu kepada masyakarat. Komunikasi politik dilakukan melalui berbagai saluran komunikasi politik. Berbagai saluran komunikasi politik baik saluran komunikasi politik massa, interpersonal dan organisasi digunakan untuk dapat mempengaruhi keputusan memilih masyarakat. Setiap saluran komunikasi politik tentu saja memiliki tingkat pengaruh yang berbeda-beda pada masyarakat. Oleh karena itu, penelitian ini mencoba menyelidiki pengaruh dari berbagai saluran komunikasi politik yang digunakan pada pemilu legislatif DPR RI Kota Bogor terhadap keputusan memilih masyarakat. Penelitian ini mencoba menyelidiki saluran komunikasi politik antara lain saluran komunikasi politik massa (kampanye terbuka, media massa televisi, media sosial, baliho/poster dan koran), saluran komunikasi interpersonal (dialog tatap muka, blusukan dan relawan) dan saluran komunikasi organisasi (tokoh agama). Berbagai saluran komunikasi politik tersebut menjadi variabel independen yang mempengaruhi variabel dependen, yaitu keputusan memilih partai. Model penelitian diuji menggunakan analisis regresi logistik multinominal.

Hasil penelitian memberikan temuan bahwa kampanye terbuka, media sosial, blusukan, relawan dan tokoh agama mempengaruhi keputusan memilih partai pada pemilih di Kota Bogor. Sedangkan media televisi, baliho/poster, koran dan dialog tatap muka terbukti tidak berpengaruh dalam keputusan memilih. Temuan penelitian dapat diterapkan oleh para peserta pemilu ataupun pelaku politik lainnya untuk mengefektifkan komunikasi politiknya dengan masyarakat dan implikasinya untuk pembangunan demokrasi yang berkelanjutan. Para peserta pemilu dapat tetap menggunakan seluruh saluran komunikasi politik secara bersama-sama namun dengan memberikan prioritas sumberdaya kepada kelima saluran komunikasi yang terbukti memiliki pengaruh signifikan terhadap keputusan memilih. Prioritas alokasi sumberdaya kampanye yang dilakukan oleh partai politik dan kandidat politik akan berdampak kepada efisiensi biaya kampanye dan secara jangka panjang akan mempengaruhi iklim pembangunan demokrasi di Indonesia. Selain itu, temuan penelitian juga dapat digunakan oleh para tokoh politik diluar pemilihan umum dengan menggunakan saluran komunikasi yang terbukti dapat mempengaruhi masyarakat sehingga informasi politik dapat diterima dengan baik oleh masyarakat dan masyarakat pun dapat menyampaikan aspirasinya kepada para pelaku politik ataupun pemegang kepentingan. Dengan komunikasi politik yang terjalin dengan baik maka komunikasi pembangunan juga akan dapat terbangun dengan baik di segala bidang, khususnya demokrasi. 


\section{UCAPAN TERIMA KASIH}

Penghargaan yang tinggi beserta ucapan terima kasih untuk tim The Indekstat Research and Data Science Institute yang telah mendukung dan memfasilitasi penelitian kuantitatif ini sehingga bisa memberikan persfektif lain dalam kajian keputusan memilih khususnya di Kota Bogor.

\section{DAFTAR PUSTAKA}

Aguirre, G. C., \& Hyman, M. R. (2015). The marketing mix and the political marketplace. NMSU Business Outlook, 13(3).

Aly, B. (2010). Komunikasi Pembangunan Dengan Aksentuasi Komunikasi Politik. Jurnal Komunikasi Pembangunan, 8(2), 246668. https://doi.org/10.29244/jurnalkmp.8.2.

Anshori, A. (2018). Pengaruh Iklan Politik Terhadap Persepsi Pemilih Kota Medan Tahun 2018. Jurnal Interaksi, 2(2), 132-144. https://doi.org/https://doi.org/10.30596/interaksi.v2i2.2091

Anwar, A. (2003). Komunikasi Poitik: Paradigma-Teori-Aplikasi-Strategi dan Komunikasi Politik Indonesia. PT Balai Pustaka.

Arianto, B. (2016). Fenomena Relawan Politik dalam Kontestasi Presidensial 2014. Jurnal Ilmu Sosial Dan Ilmu Politik, 18(2), 130. https://doi.org/10.22146/jsp.13128

Cangara H. (2009). Komunikasi Politik: Konsep, teori dan strategi. Rajawali Press.

Creswell, J. W. (2016). Research Design: Pendekatan Metode Kualitatif, Kuantitatif, dan Campuran. SAGE Publication.

Cwalina, W., Falkowski, A., \& Newman, B. I. (2015). Political marketing: Theoretical and strategic foundations. Routledge. https://doi.org/10.4324/9781315701684

Deželan, T., \& Maksuti, A. (2012). Slovenian election posters as a medium of political communication : an informative or persuasive campaign tool? Communication, Politics \& Culture, 45, 140-159.

Esser, F., \& Pfetsch, B. (2004). Comparing political communication: Theories, cases, and challenges. Cambridge University Press. https://doi.org/10.1017/CBO9780511606991

Gama, B., Sudardi, B., Abdullah, W., \& Wijaya, M. (2019a). Construction of Blusukan Meaning in the Campaign of Regional Heads. Social Science and Humanities Journal, 3(07), 1416-1427.

Gama, B., Sudardi, B., Abdullah, W., \& Wijaya, M. (2019b). Blusukan Cultural as a Political Power in The Regional Head Election of Surakarta. 2nd Workshop on Language, Literature and Society for Education, 2282681. https://doi.org/10.4108/eai.21-12-2018.2282681

Gerber, A. S., Gimpel, J. G., Green, D. P., \& Shaw, D. R. (2011). How large and long-lasting are the persuasive effects of televised campaign ads? Results from a randomized field experiment. American Political Science Review, 105(1), 135-150. https://doi.org/10.1017/S000305541000047X

Gordon, B. R., \& Hartmann, W. R. (2013). Advertising effects in presidential elections. Marketing Science, 32(1), 19-35. https://doi.org/10.1287/mksc.1120.0745

Hallin, D. C., \& Mancini, P. (2004). Comparing media systems: Three models of media and politics. Cambridge University Press. https://doi.org/10.1017/CBO9780511790867

Hermanto, J., Purwatiningsih, A., \& Muhamad, R. (2020). Pengaruh isu, figur, rekam jejak dan partai politik terhadap partisipasi pemilih dalam pemilihan presiden (pilpres) tahun 2019. REFORMASI, 10(1), 27-33. http://dx.doi.org/10.33366/rfr.v10i1.1694

Hosmer, D. W., \& Lemeshow, S. (2000). Applied logistic regression (2nd Ed.). John Wiley \& Sons, Inc.

Kaid, L. L. (2004). Handbook of Political Communication Research (2n Ed.). Lawrence Erlbaum Associates.

KPU. (2018). Peraturan Komisi Pemilihan Umum Nomor 33 Tahun 2018. https://jdih.kpu.go.id/data/data_pkpu/PKPU 33 THN 2018.pdf

KPU. (2019). KPU Jawa Barat Gelar Evaluasi Partisipasi Masyarakat Dalam Pemilu 2019. KPU Jabar. https://jabar.kpu.go.id/2019/09/kpu-jawa-barat-gelar-evaluasi-partisipasi-masyarakatdalam-pemilu-2019/

Muhammad, A. (2016). Komunikasi Politik Dalam Pembangunan dan Perubahan Sosial. Kompasiana. https://www.kompasiana.com/desanomics/57e0f5f3c923bd9f0d0b331e/komunikasi-politik- 
dalam-pembangunan-dan-perubahan-sosial?page=all

Muslim, A., Kolopaking, L. M., Dharmawan, A. H., \& Soetarto, E. (2015). Dinamika Peran Sosial Politik Ulama dan Jawara di Pandeglang Banten. MIMBAR, Jurnal Sosial Dan Pembangunan, 31(2), 461. https://doi.org/10.29313/mimbar.v31i2.1555

O'cass, A. (2002). Political advertising believability and information source value during elections. Journal of Advertising, 31(1), 63-74. https://doi.org/10.1080/00913367.2002.10673661

Putra, A. M. (2011). Media Baru dan Fenomena Komunikasi Politik pada Pemilukada di Provinsi Banten 2011. Jurnal ULTIMA Comm, 3(2), 23-34. https://doi.org/10.31937/ultimacomm.v3i2.203

Quintelier, E., \& Hooghe, M. (2011). Television and political participation among adolescents: The impact of television viewing, entertainment and information preferences. Mass Communication and Society, 14(5), 620-642. https://doi.org/10.1080/15205436.2010.530383

Riaz, S. (2014). Effects of New Media Technologies on Political Communication. Journal of Political Studies, 1(2), 161-173.

Ron, S. (2009). The political participation puzzle and marketing. Journal of Marketing Research, 46(6), 798-815. https://doi.org/https://doi.org/10.1509/jmkr.46.6.798_JMR6H

Safiullah, M., Pathak, P., Singh, S., \& Anshul, A. (2017). Social media as an upcoming tool for political marketing effectiveness. Asia Pacific Management Review, 22(1), 10-15. https://doi.org/10.1016/j.apmrv.2016.10.007

Sanit, A. (2015). Pematangan Demokrasi dan Sistem Politik Indonesia: Kendala Pelembagaan dan Kepemimpinan. Jurnal Politik, 1(1), 155-175. https://doi.org/https://doi.org/10.7454/jp.v1i1.12

Siagian, H. F. (2012). Pengaruh Kredibilitas Komunikator Politik Untukmendapatkan Dukungan Khalayak Dalam Pemilihan Umum. Jurnal Dakwah Tabligh, 13(2), 281-291. https://doi.org/https://doi.org/10.24252/jdt.v13i2.310

Subakti, R. (2007). Memahami Ilmu Politik. Grasindo.

Sugiyono. (2017). Metode Penelitian Kombinasi (Mixed Methods). Alfabeta.

Sumarwan, U. (2003). Perilaku Konsumen: Teori dan penerapannya dalam Pemasaran. Ghalia Indonesia.

Susanto, E. H. (2017). Media Sosial sebagai Pendukung Jaringan Komunikasi Politik. Jurnal ASPIKOM, 3(3), 379-398. https://doi.org/10.24329/aspikom.v3i3.123

Venus, A. (2004). Manajemen Kampanye: Panduan Teoritis Dan Praktis dalam Mengefektifkan Kampanye Komunikasi. Simbiosa Rekatama Media.

Zulkarnain, A., \& Harris, S. (2017). Fenomena Blusukan Dalam Model Kepemimpinan Politik Joko Widodo. Jurnal Politik Universitas Nasional, 13(1), 1928-1942. 